\title{
Robotjul i Ans
}

\section{- Om teknologiforståelse indlejret i scenariedidaktik}

\section{Johannes Fibiger}

Lektor ved VIA og medarbejder på

videncenter for læring og IT

FabLab-pioner på Campus Bindslev, Silkeborg.

\section{Line Lund Jørgensen}

\section{Lærer ved Ans Skole}

FabLab-pioner på Campus Bindslev, Silkeborg.

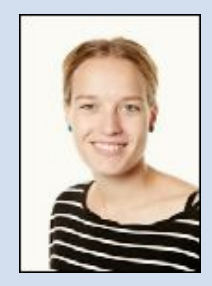

\section{Abstract}

I denne artikel undersøger og udvikler vi forskelige teknologiforståelser gennem en konkrete case fra en intervention på Ans skole i Jylland. Udgangspunkter er et forløb i 3. klasse, hvor en interaktiv julekalender forbinder en fiktionsfortælling med et lokalt scenarie. Indlejret i disse rammer afprøver vi to teknologier: 3D-modellering og printning på den ene side og robotprogrammering på den anden. Det gennemgående træk i casen er, at eleverne producerer, analysere og programmerer ting, der dermed forbinder dem med et scenarie. Det er med dette greb, at vi gerne vil udvikle forståelse.

Vores artikel er et case-studium, der bygger på observationer, interview og videooptagelser. Vi analyserer vores data ud fra en hermeneutisk tilgang, hvor vi ønsker at undersøge elevernes scenariekompetence og begyndende 
teknologihåndtering. Casens styrke ligger ikke i evidens, men i evnen til at se noget: At sætte et eksempel, som der kan tænkes over og ud fra. Målet er ikke at skabe evidens, men tværtimod at reflektere ud fra det partikulære. Det redegør vi for i artiklens metodeafsnit. Det konkrete afsæt er altså erfaringerne fra en intervention, som danner basis for en diskussion af forskellige teknologiforståelser, og som argumenterer for, at teknologiforståelse både involverer et forståelses-, et handlings- og et etisk perspektiv.

\section{English abstract}

In this paper, we study and develop various perceptions of technology based on a specific case study tested at Ans state school in Jutland. The basis is a course of study in a class of third year pupils in which an interactive advent calendar combines a fictional story with regional sites. Embedded in this framework, we test two technologies:

$3 \mathrm{D}$ modeling and printing on the one hand, and robot programming on the other hand.

Our paper is a case study based on observations, interviews and video recordings. We analyze our data by means of a hermeneutic approach in order to study the pupils' ability to understand a specific setting and nascent technological skills. The objective is not to come up with evidence, but on the contrary to reflect on the experiences. We intend to account for this point in the section on the methodological approach of this paper. The experiences acquired from testing constitute the background for a discussion of various perceptions of technology and it is argued that perception of technology includes aspects of learning, action and ethics.

\section{Indledning - problemidentifikation}

A gathering, that is, a thing, an issue, inside a Thing, an arena, can be very sturdy, too, on the condition that the number of its participants, its ingredients, nonhumans as well as humans, not be limited in advance.

(Latour, 2004 s. 246)

I den dagsordensættende artikel "Why have Critique Run out of Steam" (2004) undersøger Bruno Latour bl.a., hvad en 'ting' er. Etymologisk kobler han betydningen til det oldnordiske ting, som vi kender fra tingsteder, hvor et samfunds individer mødes, diskuterer, beslutter eller dømmer om, hvordan et anliggende skal løses. Latour vil gerne fastholde den oprindelige betydning af ordet i opposition til Heidegger og Kant, der genstandsgør en ting. For Latour er en ting et mødested mellem aktører. Latour definerer en aktør som 'et resultat udstyret med en karakter': "En aktør i aktør- 
netværksteori er en semiotisk definition - en aktant, dvs. noget, der handler, eller som får aktivitet fra andre" (Latour, 2006 s. 214).

I denne artikel skildrer vi et konkret forløb i tredje klasse, hvor en ting, i dette tilfælde en robot, samler en række aktører i et netværk. Konteksten for forløbet er, at vi er to undervisere, som har fået bevilget et års pioneruddannelse på FabLab Silkeborg. En del af uddannelsen indebærer, at man laver to interventioner i folkeskolen. Den første af disse fandt sted i 3. klasse på Ans Skole, hvor Line Lund Jørgensen er dansklærer.

Vi mener, at det ofte er et problem i interventioner med teknologier, at teknologien bliver noget ydre, der frakobles kontekst, så eleverne lærer at programmere eller 3D-printe, men ikke kan se teknologierne i et virkelighedsperspektiv. Målet med interventionen var derfor at forbinde anvendelsen af forskellige teknologier i et scenarie, så eleverne kunne lave transfer fra et fiktivt scenarie over i et faktivt. Det fiktive univers er litterært, den faktiske kontekst er Ans.

Ved at forbinde en række ting: julekalender, en fortælling, et bykort, nogle robotter, et juletræ og noget pynt; har vi skabt et scenarie, som bliver forbundet til et netværk gennem aktiviteterne i tredje klasse. Spørgsmålet er, hvad eleverne lærer, når de skal designe og 3D-printe julepynt, programmere robotter til at omsætte en fiktiv fortælling til en rute på et bykort, og når eleverne skal demonstrere og fremlægge deres forløb for klassen.

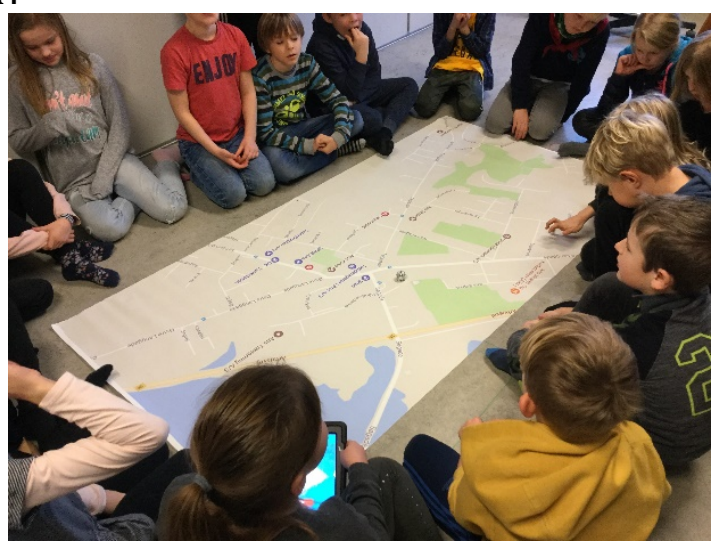

Figur 1: Fremlægning af kodningsopgave i 3.a. Billedet illustrerer et netværk med mange aktører, hvor nogle er humane, andre tekniske og rammen semiotisk, da fiktionen forbinder handlingen med bykortet.

Det ville vi gerne finde ud af ved at afprøve forløbet i december 2017. Artiklens metode, fund og argumentation vil fremgå af de følgende afsnit. Målet er at diskutere digital dannelse og teknologiforståelser på baggrund af casen fra Ans. Det betyder, at artiklen falder i to dele. Først en indledning, metode og resultater, der viser forløbet og dets fund, derefter følger argumentation og diskussion, der forholder erfaringerne fra casen til det mere overordnede tema 'teknologianvendelse i skolen'. Artiklen skildrer et forløb, der bruges som afsæt for refleksion. Der er altså ikke tale om et forskningsprojekt, der skal generere valide data, men en intervention, hvor teknologi bliver afprøvet i undervisning, der tjener som en fortælling, der bygger på praksiserfaringer i et felt uden megen praksis.

\section{Metode}

Det er rigtigt, at opsummering af casestudier ofte er vanskeligt, især hvad angår proces. Det er mindre rigtigt, hvad angår resultater. Problemet med at sammenfatte casestudier skyldes imidlertid oftere egenskaber ved den studerede virkelighed end egenskaber ved casestudiet som forskningsmetode. I mange tilfælde er det ikke hensigtsmæssigt at sammenfatte eller generalisere casestudier. Gode casestudier bør læses som fortællinger i deres helhed.

(Flyvbjerg, 2010 s. 485) 
I 2016 udkom bogen At se verden i et sandkorn, som belyser det eksemplariske princip (Hansen \& Ingemann, 2016). Dette kendes fra naturvidenskabens videnskabsteori, hvor fx Thomas Kuhn arbejder med paradigmatiske eksempler, der udtrykker videnskabens yndlingsforsøg og forklaringsmodeller. Det er ikke i denne forståelse, at vores artikel tænker. Vores praktiske forløb fra 3. klasse udgør et sandkorn, vi ser igennem. Princippet er, at det partikulære kan belyse noget særligt, som Flyvbjerg konkluderer i citatet ovenfor. Det, at fastfryse et netværk med mange aktører, er, som Latour så rammende formulerer det, som at tage et gruppebillede af personer i bevægelse. Det betyder, at det man ser, altid er en fortolkning og en repræsenterer en mindsket kompleksitet, der anskues selektivt. Derfor bliver casestudier kvalitative.

Casen tager udgangspunkt i et konkret undervisningsforløb, baseret på en intervention i 3. klasse. Det er en bottom up-case baseret på induktiv tilgang med henblik på at udvikle refleksion i og på handling (Neergaard, 2007, Schön 2001), det vil sige at vi reflekterer ud fra de observationer, interviews og videooptagelser med henblik på at undersøge elevernes evne til at lave transfer og tilegne sig teknologiforståelse. Vi har valgt forløbet som analyseenhed (Yin, 2009), hvilket er sket ud fra et fravalg af andre muligheder, som $\mathrm{fx}$ at studere lærer- og elevroller i designprocesser. De udvalgte fokusområder for undersøgelsen er elevernes problemløsning, kollaboration, kommunikation og teknologiforståelse. Hermed understøttes en dækkende udvalg af det 21 århundredes kompetencer (www.p21.org), hvilket ikke er et mål i sig selv, da disse kompetencer også kan ses ind i et kommercielt interessefelt fra tech-giganterne. Vores mål med undersøgelsen var at diskutere teknologiforståelse i en dansk kontekst, hvilket er artiklens hovedbestræbelse. Denne ambition var udviklet før de respektive ekspertpanelser udviklede læseplaner for faget teknologiforståelse i skolen og læreruddannelsen.

De anvendte dataindsamlingsmetoder er observationer, videooptagelser og kvalitative interviews med eleverne. Før forløbet fik vi forældrenes underskrift på, at vi måtte filme deres børn og tilladelse til, at børnene måtte oprette en bruger i TinkerCad. Navnene i casen er anonymiseret efter gældende regler. Observationerne er foretaget med Line Lund Jørgensen som deltager (lærer) og Johannes Fibiger som observatør (udefrakommende). Det er klart, at begge positioner påvirker det, der iagttages. Der findes ikke versionsfrie sandheder, heller ikke når det gælder kvalitative studier. Så det at eleverne bliver filmet og interviewet påvirker selvfølgelig deres adfærd, men det er et vilkår i alt feltarbejde.

Videooptagelserne er optaget af de grupper, der programmerede robotter uden medvirken af voksne med det mål at få anskueliggjort elevernes kollaborative processer, mens de forhandlede, blokprogrammerede og afprøvede løsningen på dagens opgave. Derudover filmede vi eleverne, når de fremlagde for klassen. Her blev de holdt op på forløbets læringsmål.

Interviewene er lavet den sidste dag efter endt forløb. Det drejer sig om et struktureret interview med en fast interviewguide på fem spørgsmål. Eleverne blev interviewet to og to af Johannes Fibiger, mens Line Lund Jørgensen forestod klassens vanlige undervisning. Eleverne blev udvalgt og sat sammen tilfældigt, således at de to, der afsluttede et interview, selv kaldte to 
ud til næste runde. Der deltog 19 ud af 23 eleverne i undersøgelsen. De tre researchmetoder supplerer hinanden og udgør som sådan en triangulering, der ikke kan eller skal bære nogen bevisbyrde, men give et mere nuanceret billede at vores intervention. Derfor udgør fundene selektive fortolkninger.

En case udgøres af et narrativ, som for at blive en fortælling allerede rummer et fortolket stykke virkelighed (Flyvbjerg 2010: 481-85). Derfor har en case begrænset videnskabelig status, fordi udgangspunktet er partikulært (Hansen og Ingemann 2016). Casens styrke ligger ikke i evidens, men i evnen til at se noget: At sætte et eksempel, som der kan tænkes over og ud fra. Om det hermeneutiske udgangspunkt skriver filosoffen Hans Georg Gadamer i sit hovedværk Sandhed og metode (1960/da: 2004):

\begin{abstract}
Erfaringen af den samfundsmæssige og historiske verden lader sig ikke videnskabeliggøre ved hjælp af naturvidenskabernes induktive metode. Hvad videnskab i denne sammenhæng end måtte betyde, og hvor meget man i al historisk erkendelse end overfører af almen erfaring på den foreliggende enkelte genstand - så stræber historisk erkendelse dog ikke efter at erkende det konkrete fænomen som en instans af en almen regel. Det partikulære fungerer ikke slet og ret som bekræftelse på en lovmæssighed, om man så i praksis kan basere sine forudsigelser på. Den historiske erkendelses ideal er tværtimod at forstå fænomenet selv som noget unikt og historisk konkret.
\end{abstract}

(Gadamer, 2004 s. 10)

Citatet demonstrerer kernen i casestudier, nemlig det narratives binding til kontekster og dets historiske temporalitet. Fortællinger fra virkeligheden har det med at visne i samme tempo som afplukkede blomster.

Uddannelsesforskeren Gert Biesta argumenterer for, at undervisning altid har en kompleksitet, der overskrider de få faktorer, der peges på i fremstillinger af, hvad der virker (Biesta, 2014). Det betyder til gengæld ikke, at kvalitative studier som vores sidder inde med en større sandhed. Den er som Gadamer oven for fastslår det lokal, temporal og kontekstuel. En tilsvarende overvejelse er sociologen Anthony Giddens inde på, når han reflekterer over generaliserbarheden i feltstudier:

Research which is geared primarily to hermeneutic problems may be of generalized importance in so far as it serves to elucidate the nature of agents' knowledgeability, and thereby their reasons for action, across a wide range of action-contexts. Pieces of ethnographic research like ... say, the traditional small-scale community research of fieldwork anthropology--are not in themselves generalizing studies. But they can easily become so if carried out in some numbers, so that judgements of their typicality can justifiably be made.

(Giddens, 1984 s. 328)

Vores fortolkning af casen foregår ud fra et ANT-perspektiv (Latour, 1996 og 1999), dvs., at vi er optagede af, hvordan interaktionen mellem 
mennesker og teknologi foregår i et givent scenearie. Metodisk har vi gennemset alle videoer, samordnet og diskuteret vores observationer, der er forskellige, fordi Line Lund Jørgensen er deltagende observatør, mens Johannes Fibiger er udeforstående. Om dette forhold skriver Giddens:

I have accepted that it is right to say that the condition of generating descriptions of social activity is being able in principle to participate in it. It involves 'mutual knowledge,' shared by observer and participants whose action constitutes and reconstitutes the social world.

(Giddens 1982 s. 15)

Vores analyse af observationer, video og interview baserer sig på en hermeneutisk videnskabsteori, hvor observationer og videoanalyse a priori er indlejret i nogle forståelseshorisonter, der er givne qua konteksten og vores forudfattede viden. Det rejser risici for bias på verifikation, dvs. at vi læser elevernes interaktioner mere positivt, end det kan bære for at fremme vores mål. Denne fejlkilde har vi blik for, og vi kan derfor også i vores fund konstatere, at eleverne ikke opnår den teknologiforståelse, vi havde håbet på.

Det fremgik af vores afsluttende interviews. Her anvendte vi denne interviewguide:

1. Hvordan gik det med at samarbejde om robot-opgaven?

a. Hvad var svært?

b. Hvad var nemt?

2. Hvordan var det at skulle fremlægge foran klassen? Begrund, hvorfor det var svært eller let at forklare, hvad i gjorde og hvorfor.

3. Hvordan var det at arbejde med Tinkercad?

a. Hvad var svært?

b. Hvad var nemt?

4. Hvad har du lært af forløbet?

5. Hvorfor tror du, at I skal arbejde med 3D-print og robotter i skolen?

Figur 2: Interviewguide til 3. klasse.

Spørgsmål 1 og 3 handlede om mestring, hvor eleverne sagtens kunne pege på deres egne udfordringer og færdigheder. Spørgsmål 2 gav fyldige svar, hvor eleverne var gode til at forklare, hvad de havde gjort. Denne observation støttes af vore videoobservationer. I spørgsmål 4 holdt vi eleverne op på læringsmålene, og her mente de fleste elever, at de havde lært at 3Dmodellere og at kode robotterne. Det sidste spørgsmål blev skuffende besvaret. Eleverne havde svært ved at sætte ord på, hvorfor og hvad de skal kunne bruge programmering til uden for skolen. 
Vores diskussion er fokuseret på digital dannelse og teknologiforståelse. For at kunne italesætte de to fænomener på en teoretisk kvalificeret måde, er det nødvendigt at inddrage Humboldt, Hegel, Gadamer og Klafki på dannelsesdimensionen, og Gadamer, Heidegger og Latour på teknologiforståelsen. Man skal derfor læse artiklen sådan, at casen udgør empirisk basis for artiklens overordnede teoriudvikling og diskussion. Artiklen falder i to dele: 1) et praktisk forløbsbeskrivelse af en intervention, der blev brugt som 2) afsæt for teoretisk refleksion, ikke om generering af forskning og valide data.

\section{Forløbet}

\section{sug'ar'coat}

1. To cause to seem more appealing or pleasant: a sentimental treatment that sugarcoats a harsh reality.

2. To coat with sugar: sugarcoat a pill. (Opslag fra https://www.thefreedictionary.com/sugarcoating)

Vores overordnede idé før interventionen var at designe et forløb, hvor en eller flere teknologier kunne understøtte danskundervisning og tilføje den en dimension, som ikke kunne tilføres gennem andre redskaber. Teknologien skulle ikke bare være en motivationsfaktor i form af nyt 'legetøj'. Sugarcoating er en betegnelse fra medicinalindustrien, hvor man forsyner piller med en sukkerkappe for at få patienter til at spise dem. Begrebet bruges også i pædagogiske kontekster, hvor man pakker en kedelig opgave ind i en sjov form. Dette ønskede vi at komme udover!

Da interventionen foregik i december, besluttede vi efter længere tids idegenerering at lave en interaktiv julekalender, der kunne forbinde den årligt tilbagevendende kalenderlæsning og julepyntning med et teknologi-indhold. På den måde kunne det narrative bære teknologien ind i danskfaget. Vi ønskede, at eleverne skulle opnå en scenarieforståelse for at understøtte læseforståelsen.

Scenariedidaktik baserer sig på forløb, hvor eleverne "indgår i en praksis, et scenarie, hvor der er nogle at kommunikere med, forskellige opgaver, evt. forskellige roller til forskellige elever samt et reelt produktionsmål" (Bundsgaard, Misfeldt \& Hetmar 2012, s. 30). Undervisning ud fra dette koncept handler om anvendt faglighed, dvs. at meningsfuldhed er en forudsætning og transfer er et bærende princip, forstået på den måde at isolerede fagligheder ikke trænes i sig selv, men integreres i en helhed.

Vores mål var at gøre forløbet aktuelt og nærværende for eleverne ved at inddrage julekonteksten og elevernes egen livsverden. Historien skulle derfor foregå i deres nærmiljø og være en nisse-rejse rundt i Ans By på jagt efter kirkens julepynt. Efter research på biblioteket valgte vi kalenderbogen Jagten på det stjålne julestjerne (Faurby, 2001), som vi remedierede, så den passede til scenariet. 

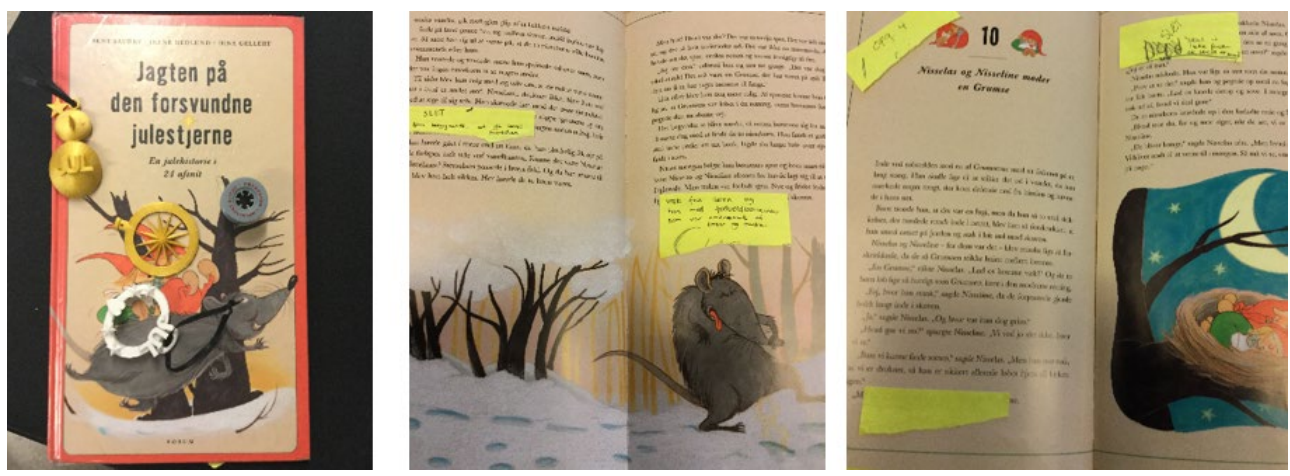

Figur 3: Remediering af "Jagten på den forsvundne guldstjerne", så handlingen flyttes fra nisseland til Ans.

Herefter bestilte vi på nettet en voksdug med et trykt bykort over Ans By. Valget af robottype faldt på Ozobotter ud fra en overvejelse omkring, hvad vi ville investere i, og hvilke perspektiver vi havde for programmering på skolen. Ozobotterne har den åbenlyse fordel, at de både kan linje- og blokprogrammeres. Ruten kan nedbrydes i trin, så det bliver overskueligt for eleverne at analysere og eksekvere deres kodning. Dette gør Ozobotterne meget intuitive at arbejde med.

Samtidig var det ud fra en betragtning om, at progressionen for at lære programmering kan starte ved linjeprogrammering og udvikle sig til blokprogrammering. Dermed kunne vi med Ozobotterne se mange potentialer for forskellige forløb fremover - uanset om man går i 0. eller 6. klasse. I dette forløb skulle eleverne blokprogrammere på en iPad. Blokprogrammeringen foregik på engelsk, så derfor havde vi arbejdet tværfagligt med engelsk, for at eleverne fik den sproglige del med.
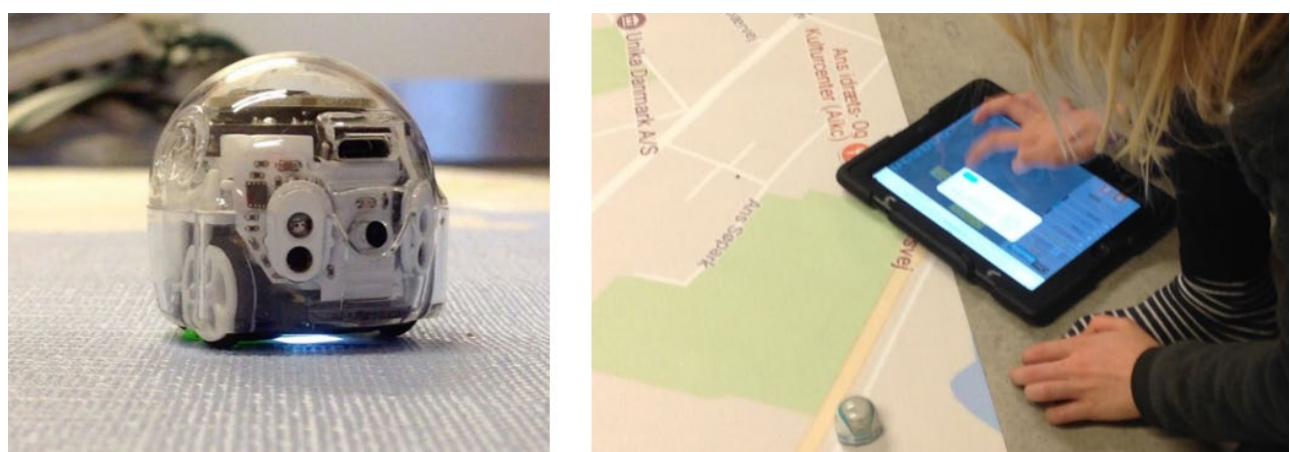

Figur 4: Ozobot er en lille robot, som ligner R2D2. Til venstre eksekveres en kodning af pige i tredje klasse.

Som introduktion til forløbet lavede vi i slutningen af november julepynt i 3Dprint i programmet TinkerCad. Vi havde forinden lavet en manual med screenshots fra TinkerCad, men det viste sig hurtigt, at eleverne var langt mere spontane og intuitivt lærende, end vi havde forestillet os. De gik direkte til sagen uden at studere manualen. Hvis de manglede hjælp, skulle de kigge i manualen, før de opsøgte vejledning. Et vigtigt aspekt af makerkultur består i, at eleverne opnår self efficacy, dvs. tiltro til egne evner og det at kunne arbejde vedholdende med en udfordring, hvor man prøver selv eller samarbejder frem 
for at spørge læreren. Vores observationer viste, at denne arbejdsform bekom 'gamer-drengene' godt, fordi de kunne lave transfer fra deres fritidsliv ind i skolen. Lang tids erfaring med computerspil havde lært dem trial and errorprocesser, så det at fejle er en del af læringen. Derimod var arbejdsformen en udfordring for de mere tilbageholdende piger, der var vant til rigtige og forkerte svar og gerne ville lærerens hjælp og opmærksomhed.

Eleverne var helt med på, at det var deres første forløb med 3D-print, og at vi måtte lære det sammen. Nogle elever opdagede funktioner, underviserne ikke kendte til og kunne derfor vejlede deres kammerater - det gav en stærk fællesskabsfølelse og stolthed over bemestring!

Fra decembers start oplæste vi dagens kapitel og udtrak en tilfældig gruppe, hvis julepynt blev hængt på juletræet, når de havde løst, udført og formidlet dagens kodningsopgave. Hver dag skulle nisserne et nyt sted hen $\mathrm{i}$ byen for at lede efter det stjålne julepynt. Ozobotterne var nisser og rejste rundt på vores store bykort. Ved hjælp af programmet OzoBlockly blokprogrammerede dagens gruppe en Ozobot til at køre den korrekte rute på kortet.

Først når dagens opgave var løst, kunne gruppen hænge sin julepynt på klassens træ. Herefter skulle det præsenteres for klassen og evalueres på de opstillede læringsmål. Sjældent har vi oplevet en klasse sidde i rundkreds og være så stille og opmærksomme på de klassekammerater, der fremlagde. Bykortet gjorde, at eleverne havde let ved at engagere sig og relatere til det, da det visualiserede deres livsverden. Et godt eksempel på den transfer, eleverne lavede fra deres faktuelle verden ind i fiktionsfortællingen var, da Rikke siger "Pas på, du ikke kommer ud på den store vej og bliver kørt ned!" til sin kammerat, som styrer Ozobotten.
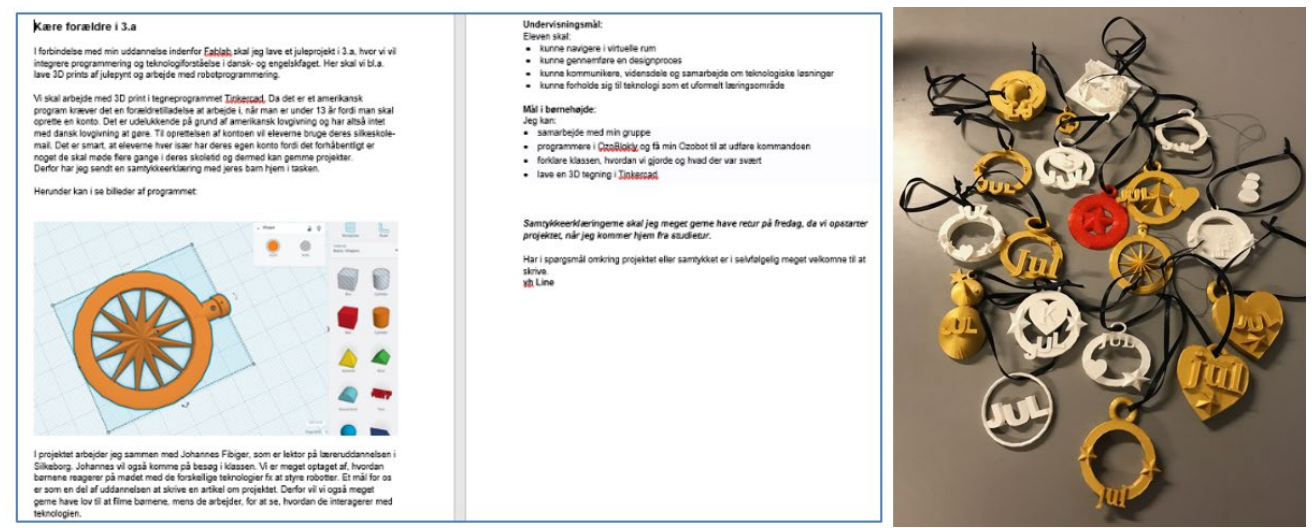

Figur 5: Tv :Forældrebrev med læringsmål og introduktion til TinkerCad, th. resultatet af en fagdags produktion: julepynt i forskelligt design med ophæng.

Forløbet havde disse rammefaktorer:

- Fag: Dansk

- $7 \times 1$ time $+2 \times 4$ timer (fagdage)

- 1-2 lærere

- 22 elever

- 3. klassetrin 
- 2 3D-printere

- 4 Ozobotter

Det didaktiske design blev udm $\varnothing$ ntet i en lektionsplan, der blev sammenholdt med læringsmål og tegn på læring, som vi vender tilbage til om lidt. Vores intervention havde dette design: Aktivitetsplan, læringsmål/tegn/evaluering og materialer (se figur 5):

\begin{tabular}{|c|c|c|}
\hline AKTIVITETSPLAN & LERINGSMÁL/TEGN PÅ LERING/EVALUERING & MATERIALER \\
\hline 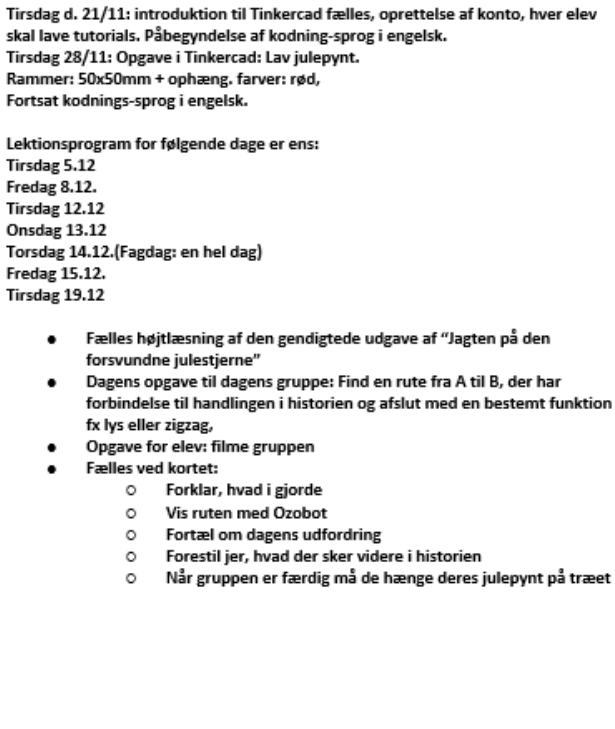 & 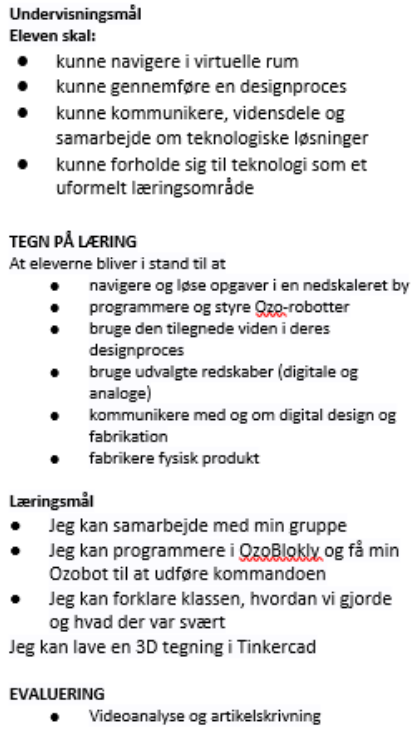 & $\begin{array}{ll}\text { MATERIALER } \\
: \text { Voksdug med print } \\
: \text { Bærbar computer } \\
: \text { iPads } \\
: \text { Jd printer + flere farver filament } \\
: \text { Tinkercad } \\
\text { Surca }\end{array}$ \\
\hline
\end{tabular}

Figur 6: Didaktisk design for intervention.

\section{Resultater}

Man skal kunne forskelige ting med computere. Fx har jeg hørt, at man kan 3D-printe huse og måske vil alle huse en dag blive 3D-printede. Så det er godt at vide.

(Elev i 3. klasse)

Citatet oven for stammer fra de interviews, vi lavede med eleverne den sidste dag. Denne dreng er i stand til at lave transfer fra et scenarie til et andet, nemlig fra hans egen 3D-modellering af julepynt til den virkelige verden, hvor 3D-printere i dag indgår industriel produktion og i særegne tilfælde i bygning af huse. Men citatet er ikke repræsentativt, da de fleste elever ikke mestrede at applicere deres indsigter fra forløbet på relevante aspekter uden for klassen.

Under 3D-forløbet var det blevet tydeligt, at elevernes forudsætninger var meget forskellige. De såkaldte "gamer-drenge" var vant til at forholde sig til og navigere i et virtuelt rum. De har en umiddelbarhed, som ofte kontrolleres og bremses i skolen og de kunne lave transfer fra deres erfaringer med computerspil over i arbejdet med 3D-modellering og

blokprogrammering. Her fik den intuitive tilgang lov til at styre, og det bragte 
dem til steder i programmerne, hvor vi som undervisere ikke havde været. Det gjorde noget ved lærer-elev-relationen, der pludselig forskød sig, fordi andre elever kunne sætte dagsordenen og være i et ligeværdigt forhold med læreren.

Vores observationer viste, at eleverne tog et ansvar for, at alle i gruppen lykkedes med at printe julepynt og gennemføre deres kodningsopgave. Et af vores fund bestod $\mathrm{i}$, at vi fejlvurderede, hvor stort deres pynt reelt blev, når det kom ud af printeren og forståelsen for, at elementerne i figuren skulle hænge sammen, så julepynten ikke faldt fra hinanden, når den blev printet. $\mathrm{Vi}$ gik sammen med eleverne ind og rettede deres design til og printede igen.

Denne iterative proces synliggjorde væsentligheden af figurens opbygning for dem. Efterfølgende blev det tydeligt, at eleverne er blevet mere opmærksomme på ny teknologi, og hvad den kan bidrage med i deres hverdag. Flere elever har nævnt forskellige eksempler på noget, der kunne være smart at 3D-printe eller spurgt ind til funktioner om 3D-printerens affordances.

Under historieforløbet indledte vi hver time med at snakke om gårsdagens kapitel. Vi er meget overraskede over, hvor meget projektet bidrog til elevernes scenariekompetence og læseforståelse. Scenarieforståelse handler om at opbygge indre forestillingsbilleder og lave inferens mellem tekstens dele. Derved styrkes læseforståelsen og det gør den især, hvis den anvendes til at løse en opgave med, hvor det læste scenarie skal materialiseres i fx en model, et produkt eller i vores tilfælde en kodningsopgave (Brudholm 2011). Et centralt fund bestod i, at vi kunne observere større deltagelse i den fælles samtale om teksten. Der var langt flere elever end normalt, der kunne fortælle i detaljer, hvad der var sket og hvorfor. Mange af dem huskede simpelthen handlingen ud fra, hvor og hvordan robotten havde kørt på kortet, $f x$ at den drejede rundt ude i søen, fordi den blev slugt af en tudse.

Fordi Ozobotterne er så umiddelbare at arbejde med, blev succesraten højere, fordi opgaven fik et strejf af leg, da det handlede om at kode på iPad og eksekvere en kode på robotten. Det, at man får en ting til at udføre en handling, oplevede eleverne som en forlængelse af de erfaringer de har fra fritidslivet.

Efter hver dags-session samlede vi klassen omkring bykortet, og gruppen fremviste deres eksekvering af ruten.

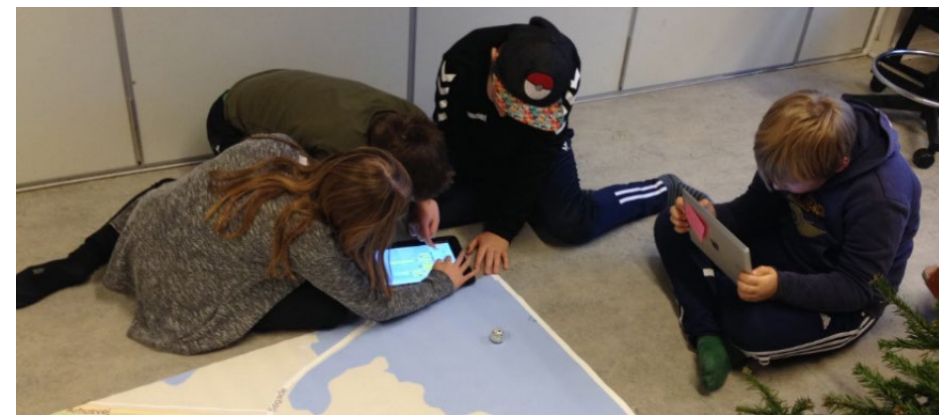

Figur 7: Kollaborativ løsning af en kodningsopgave. En elev filmer, mens de andre blokprogrammerer.

Bagefter evaluerede vi mundtligt, så hver fremlægning blev sat i relation til læringsmålene. En elev filmede gruppen, mens den arbejde og lærerne ikke var til stede. Dette gjorde vi for at kunne se elevernes samarbejdsprocesser, når vi ikke var til stede. Dette metodiske greb foretog vi for at mindske bias fra lærerindblanding - og for at eleverne ikke skulle performe med det mål at få ros af læreren.

Vores iagttagelser fra disse videoer viser, at eleverne uddelegerede opgaver, og at en påtog sig lederrollen. Der var en udbredt grad af forhandling. På en video diskuterer eleverne indbyrdes, hvordan de sletter en fejlagtig kommando, i en anden diskuterer de rækkefølgen af sekvenser i blokprogrammeringen. I en tredje video havner Ozobotten i søen i stedet for 
på den ønskede destination, hvorfor programmeringen må gå om. I eksekveringen af en kodning, får eleverne en feedback fra teknologien, som de handler på.

Denne iterative proces skaber læring, fordi eleverne gennem forhandling og trial-and-error lærer, at det er ok at fejle, for det er gennem fejl og fejlretning, at man opnår mestring. Af samme grund var nogle elever mere tilbageholdende, fordi de ikke brød sig om fejl, men gerne ville gøre tingene perfekt i første forsøg. Som sådan spejler denne lille interaktion mellem netværk og ting en kultur. I relation til aktør-netværks-analyse, er samspillet mellem menneskelige aktører, robotter og repræsentationsformen "et bykort", at der synliggør sig oversættelser mellem kognitive mønstre, iPad'ens abstraktion i kodesprog, eksekvering med en robot og scenarietransfer fra julefortælling til bykort.

Det, at programmeringen blev gjort til genstand for forhandling, hvor eleverne diskuterede alternativer ud fra en fejlslagen eksekvering, er en relevant observation, fordi debugging (fejlfinding) udgør en vigtig del af Computational Thinking og har stor læringsmæssig værdi, fordi man diskuterer steps og rækkefølger i en algoritme, og dermed kommer til at anvende og gradvist mestre et abstrakt kodesprog. Dette sprog er indlejret i alle vore hverdagsteknologier, og selv om eleverne i 3. klasse endnu ikke kan se denne transferværdi, er første skridt taget i udviklingen af en teknologisk literacy.

Når eleverne fremlagde, filmede vi også, men her var lærerne til stede og udøvede klasseledelse. I denne fase gjorde vi det fund, der havde størst generaliserbarhed, nemlig at eleverne i høj grad kunne reflektere over deres arbejdsproces - især samarbejdet formåede de at sætte ord på. Det viste sig hurtigt, at langt de fleste grupper havde været meget organiseret i, hvordan de arbejdede sammen - hvem laver hvad og hvornår. Her viste de igen, at de gerne vil have, at projektet lykkedes, fordi de var så villige til at imødekomme hinandens ønsker.

Andre fund stritter i forskellige retninger. For det første bemærkede vi, at næsten alle elever, tillagde robotten menneskelige egenskaber og egen vilje, selv om det ikke var en humanoid robot. Dette projektive træk er udbredt, både når mennesker omgås dyr, brugsting og teknologier. For det andet gjorde vi nogle lavpraktiske fund, $\mathrm{fx}$ at elever påpegede, at de havde lært at bruge en mus, hvad der er en vigtig kompetence i 3D-modellering. Andre pegede på, at de havde lært at lave steps i blokprogrammering. Generelt tegnede der sig et billede af, at eleverne kunne lave transfer fra julekalenderhistorie til programmering af robotters rute på bykortet, men at transfer ud til virkeligheden ikke lykkedes.

Dog fandt vi to interessante undtagelser. En elev vidste, som det fremgår af citatet ovenfor, at man kunne 3D-printe huse, mens en anden satte forløbet $\mathrm{i}$ relation til hendes fars arbejde med robotter på en nærliggende virksomhed. Den sidste observation er interessant, fordi transfer til det nære miljø her gav mening, endda i forhold til lokal produktion. Det mærkelige ved elevens statement var imidlertid, at hun først den sidste dag fik øje på relevansen mellem farens arbejde og aktiviteterne i vores scenarie-julekalender. Det skyldes, at hun blev spurgt i det afsluttende interview, og som sådan er der bias for det ledende i denne samtale. 
En anden væsentlig faktor er elevernes alder og viden om verden. Her spiller sproget en stor rolle, fordi elevernes evne til at sætte begreb på fænomener i 3. klasse er begrænset, grundlæggende fordi de tænker konkret. Der er dermed en bias på den kognitive evne til at lave transfer og sprogliggøre det lærte. Alle elever udviste en vis fornemmelse af, at robotter, 3D-print og programmering vil blive vigtige færdigheder, men de mangler sprog for og viden om verden til at kunne se større perspektiver.

Teknologiforståelse er nemlig ikke en ting, men handler grundlæggende om at kunne håndtere og forstå teknologier og deres sammenhæng med vores livsverden. Med denne bestemmelse har begrebet to sider:

Håndteringsaspektet, som vedrører elevernes færdigheder, og forståelsesaspektet, som både involverer en viden om verden og et kritisk perspektiv på teknologiers intentionalitet. Førstnævnte aspekt udviklede vi og kunne dokumentere i produkter og observationer, sidstnævnte er langt mere abstrakt og vanskeligere at dokumentere. Det indeholder nemlig også et dannelsesaspekt, som vi skal se på i næste afsnit.

\section{Dannelse er ikke digital}

Du har opnået digital kompetence, når du forstår både at bruge dine digitale færdigheder, så du indgår i værdiskabende sammenhænge med andre og samtidig udviser digital dannelse i din ageren på internettet. Digital dannelse er en del af at være digital kompetent. Sat på en ligning kan det udtrykkes således: Digital dannelse + digital færdigheder = digital kompetence

(Skov \& Brøndum 2016)

Ovenstående definition stammer fra Center for digital dannelse og er som sådan eksemplarisk for, hvad de fleste forstå ved begrebet. Digital dannelse handler om webetik, digitale kompetencer og kildekritik på nettet. Men dette begreb er problematisk af flere grunde. Den første er, at dannelse netop ikke er digital. Den består ikke af 0 og 1-taller (se Fibiger 2017 s. 304-12). For det andet er dannelse pr. definition personlig, kropslig, social og historisk givet og handler om at forstå sig selv og kunne begå sig i et givent samfund. Det giver således heller ikke mening at tale om teknologisk dannelse, da et sådant begreb bliver instrumentelt.

Dannelse er nemlig i sit væsen ikke-instrumentel og handler ikke om værdiskabelse, som der står i citatet ovenfor, men om at kunne indgå i en verden af teknologier, ting og mennesker. Det digitale er blot én side af de utallige teknologier, vi omgiver os med, fra bestik, der skal håndteres korrekt i spisesituationer, over turtagning i samtaler til pli i omgang og viden om verden. Dertil kommer, at dannelse i uddannelsessammenhænge er blevet brugt som modpol til målstyring, hvilket også har skævvredet begrebet, som er endt med at blive en flydende betegner:

Dannelse er et af de mest uafklarede begreber, vi har. Det skyldes ikke alene, at dannelse er en vanskelig problematik, da det handler 
om noget så grundlæggende som at blive menneske i og gennem et samfund, men også at dannelse er et middel til at fremme noget andet.

Dannelse er et af de mest centrale og omdiskuterede begreber i uddannelsesdebatten, og der er ikke nogen, der endeligt har erobret definitionsretten til dette brede og diffuse begreb. Dannelse er et normativt begreb, dvs. at det rummer nogle idealer, hvad enten det bliver brugt om børns personlighedsdannelse, faglighed, kanon eller pli.

Det tyske ord 'Bildung' rummer en kompleksitet, som angelsaksiske uddannelsestænkere ikke kan finde et begreb for på engelsk, hvorfor man benytter den tyske term. Ordet 'Bildung' trækker semantisk på ordet billede, dvs. at man skal skabes eller formes ud fra et idealbillede. Om dette forhold skriver Gadamer:
Fremkomsten af ordet dannelse genopliver den gamle, mytiske tradition, ifølge mennesket i sin sjæl bærer billedet af Gud, som det er skabt efter, og som det må opbygge i sig. Den latinske ækvivalent for dannelse er 'formatio', der i andre sprog, $f_{x}$ engelsk svarer til 'form' eller 'formation'. (...) Alligevel synes det ikke at være nogen tilfældighed, at 'dannelse' sejrer over 'form'. For bag 'dannelse' (Bildung) ligger 'billede' (Bild). Formbegrebet har ikke den hemmelighedsfulde dobbelttydighed, hvorimod billede både omfatter efterligning (Nachbild) og forbillede (Vorbild).

(Gadamer, 2004 s. 16)

Sammenligningen er interessant, fordi det tyske Bildungs-begreb rummer noget, som ikke kan indfanges i form og formgivning. Dannelsesbegrebet indlejrer nemlig en filosofi om ånden, der stammer fra romantikken. Hos Hegel bruges begrebet om paradokset at blive den, man er, hos Humboldt om almendannelse, dvs. evnen til at kunne sætte specialiseret viden i perspektiv.

I hovedværket Åndens fænomenologi (1807) bruger Hegel ca. 40 sider på at analysere den dannelsesproces, der gør ånden bevidst om sig selv. Hegel hævder, at mennesket grundlæggende lider af ulykkelig bevidsthed, fordi det er sat i verden uden formål og ikke kan finde mening i kraft af sig selv. Ved at drage ud og gøre erfaringer møder og oplever individet noget andet end sig selv, hvorved det overvinder fremmedheden og gør det fremmede hjemligt, dvs. integrerer det i sin personlighed, så man bliver bevidst om, hvem man selv er. Hegels dannelsesproces ser derfor sådan ud: Se figur 8. 


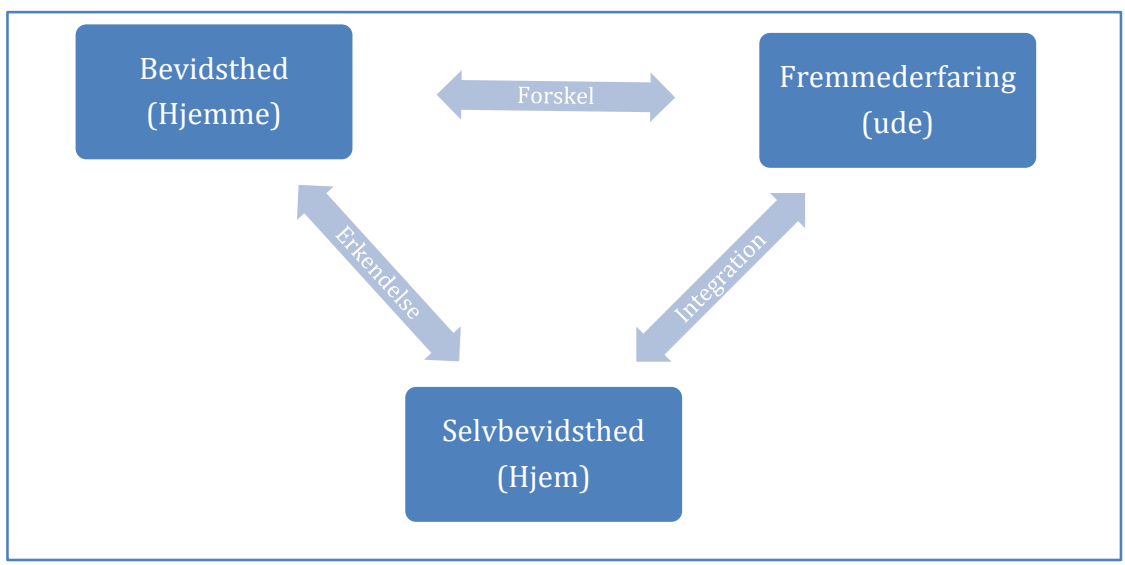

Figur 8: Dannelsesmodel ifølge Hegel. Dannelsesrejser, dannelsesromaner og eventyrets faser er alle bygget ud fra denne prototypiske model over menneskets erfaringsdannelse. Modellen er udviklet ud fra kapitel 6 i Åndens fænomenologi (Hegel 2005: 335-75).

Det centrale i denne artikels optik er, at det er ved at møde noget nyt, fx at få udfordringer med at lære nye teknologier og udvikle knowhow, at elever når til en øget omverdensforståelse. Det drejer sig om, at gøre denne læring relevant, for ellers bliver den noget ydre, og dermed integreres fremmederfaringen ikke i elevens bevidsthed. Vores forløb i Ans tog derfor netop afsæt i det kendte, julescenariet og byen Ans, for at inddrage det ukendte: 3D-print og robotprogrammering.

Det er nemlig Hegels pointe, at mennesket ved at omforme naturen og anvende teknik gør omverdenen til sin. Det sker ikke alene. Et vigtigt moment i Hegels dannelsesfilosofi består i, at man paradoksalt nok skal realisere det almene ved at individualisere sig, sådan at man på en gang bliver sin egen og kan indgå som borger i et samfund, der hviler på fællesskabets værdier og handlingsmønstre. Derfor består dannelse også i, at man lærer at forstå sig selv som menneske blandt andre. Det drejer sig derfor i vores case om eleverne evne til at samarbejde. Ved at kunne sætte parentes om sig selv og deltage i en kollaborativ proces, bliver man dannet til at være medborger.

For at få et samfund til at fungere skal man både have specialiseret viden og kunne forstå andres anvendelse af deres tilsvarende kompetencer. Dette forhold var Berlineruniversitetets grundlægger Wilhelm von Humboldt meget bevidst om. I sin programartikel Teorien om den menneskelige dannelse (1794) prøver han at beskrive, hvordan faglig specialisering kan gå hånd $\mathrm{i}$ hånd med almendannelse:

Det er ved at betragte og sammenligne de mangfoldige slags menneskelige aktiviteter, at ånden ledes til det midtpunkt, hvor alt, der påvirker os, samler sig. Ledet af dette perspektiv vil betragtningen flytte sig fra genstandenes uendelighed til det deres mangfoldige samvirke; billedet af vores aktiviteter, som vi ellers kun erkender delvist og i deres brudstykker, vil her vise sig $i$ 
et oplysende og samlende spejl på én gang, i umiddelbar relation til vores indre dannelse.

(Humboldt, 1986 s. 4, JFs oversætttelse)

Det er dette aspekt, der er i spil, når man omsætter og nedbryder et scenarie i blokprogrammering, som det sker i vores case. Bagefter skal man i fremlægningen forbinde operationerne med helheden og vurdere om læringsmålene er opfyldt. Skolens virksomhed bygger på et paradoks mellem at leve og at lære. Børn lærer ikke om tilværelsen ved at leve i den. De har brug for den omvej, der hedder undervisning (Oettingen 2016: 17). Det gælder også i vores case.

En af de pædagoger, der har gennemtænkt skolens paradoks, nemlig at man tager børnene ud af samfundet for at ruste dem til det, er den tyske didaktiker Wolfgang Klafki. Han bygger uden at sige det direkte på Hegels dialektik i sin dagsordensættende artikel "Den kategoriale dannelse" (1959). Klafki opererer nemlig med begrebet om den dobbelte åbning, dvs. at barnet åbner sig for verden og for stoffet - samtidig med, at verden og stoffet åbner sig for eleven:

Dannelse vil sige, at en fysisk og åndelig virkelighed har åbnet sig
for et menneske-dette er det objektive eller materiale aspekt.
Men det betyder samtidig, at dette menneske har åbnet sig for
denne sin virkelighed - her er det subjektive eller formale aspekt.

(Klafki, 1996 s. 192-93)

Som det fremgår, opererer Klafki både med et formalt og materielt aspekt af dannelse. Det formale handler om formningen af eleven, altså personlighedsdannelse, men den sker kun gennem mødet med det materielle: Det vil sige verden, stoffet, problemstillinger og dialogen med andre mennesker. Den materiale dannelse handler om viden og kompetencer, mens den formale dannelse handler om selvindsigt. Syntesen af de to betegner Klafki som den kategoriale dannelse, der betegner individets personlige tilegnelse af verden gennem begreber. Det er derfor eleverne i vores case skal fremlægge for klassen og forklare, hvordan de løste dagens opgave. Det er kun ved at få et sprog for teknologianvendelsen, at der i egentlig forstand læres noget. Og hermed er vi i gang med fænomenet teknologiforståelse, som vi skal se på i næste afsnit.

\section{Teknologiforståelse er altid temporal}

We cannot know who we are, or become what we are, except by looking in the material mirror, which is the historical world created by those who lived before us.

(Miller, 2005 s. 8) 
Det, materialitetsforskeren Daniel Miller taler om i citatet, er, at vi først forstår os selv, når vi spejler os i noget, vi har lavet, eller i noget, andre har lavet før os. Der sker nemlig, som Latour siger, altid oversættelser, når mennesker, ting og teknologier forbindes i netværk (Latour, 2006 s. 216-23).

Det er disse oversættelser, vi i vores case har ladet eleverne lave selv ved at forbinde julefortællingens scenarier (et narrativ) med bykortet af Ans (en repræsentation) og programmeringen af en robot (en ting). I sig selv kunne de tre fænomener sagtens generere læring, men ved at gøre dem til et netværk med aktanter, bliver eleverne aktører, der udfylder og besætter pladser i fortællingen (og i netværket).

Hvis man vil definere, hvad man egentlig mener med teknologiforståelse, bliver man nødt til at isolere ordets morfologiske rødder. Teknologi er afledt af det græske ord techne, der hos Aristoteles betegner den bestemte vidensform, der knytter sig til anvendt viden. Techne ligger $\mathrm{i}$ høj grad i hånden og det håndterbare, dvs. at kunne anvende redskaber og teknologi til praktiske formål og produktion. Suffikset 'logi' betegner 'læren om', som vi kender fra utallige afledte ord, der betegner forskellige vidensdomæner som psykologi, neurologi osv. Teknologi er altså læren om anvendt viden, der benyttes til at omforme og beherske naturen.

Men denne beherskelse har en bagside, som filosoffen Heidegger beskæftiger sig med i foredraget "Spørgsmålet om teknikken", holdt den 18. november 1953 i München. Spørger vi til, hvad teknik er, rummer det ifølge Heidegger en dobbelthed. Den ene side består i, at teknik er et middel til at nå et formål med, og at det er en menneskelig aktivitet. Dette er den instrumentelle og antropologiske bestemmelse af teknikken. Heidegger giver en række eksempler på teknologiske nyskabelser som raketten, radaren, radioen og kraftværket. Fælles for disse er beherskelsen af naturens kræfter: opdrift, vejrlig, sigtbarhed, kommunikation og energiomsætning.

Den anden side gemmer sig i teknikkens skjulte væsen og udgør noget, som ikke lader sig beherske. I teknikken kommer noget til syne, som vender sig mod mennesket. Raketten kan anvendes til masseødelæggelse, radaren til militære formål, radioen til propaganda, og kraftværkets energi kan omsættes til bomber. Det er naivt at tro, at vi behersker teknologien, for den viser sig i lige så høj grad at beherske os. Selve teknikkens væren i verden blotter en række sider af det værende, som før var skjult (Heidegger, 1999 s. 37-38).

Teknologi rummer altså en brugside og et væsen, som ikke er identiske. Væsenet viser sig paradoksalt nok i brugen og afslører sider, der ikke var tilsigtede, $\mathrm{fx}$ mobning på sociale medier, overvågning via webkameraer og cookies, der sladrer. Alle de utilsigtede sider af teknikken er noget, elever skal lære om, samtidig med at de skal kunne anvende den. De bliver med andre ord nødt til at forstå teknikkens dobbelthed, og hermed er vi fremme ved den anden rod i ordet teknologiforståelse. For hvad vil det sige at forstå noget?

Det er nemmere at forstå en forklaring end at forklare en forståelse, kunne man med idehistorikeren Hans-Jørgen Schanz sige. Spørger man Gadamer, er en forståelse altid tidsbunden og forankret i en kulturel forforståelse (Gadamer, 2004 s. 253ff). I denne artikels optik er det 
interessant, at Gadamer ofrer plads på at forholde sig til Aristoteles begreb om 'techne', dvs. anvendt viden. Om denne vidensform skriver Gadamer:

\begin{abstract}
Som viden er den altid praksisorienteret, og selv om det genstridige materiale ikke altid adlyder den, der har lært sit håndværk, så kan Aristoteles dog med rette citere digteren: "Techne elsker Týche (en gunstig skæbne), og Týche elsker Techne". Det betyder: Den, der har lært sig sine ting, opnår også for det meste også et vellykket resultat. Hvad man erhverver sig $i$ techne er en ægte beherskelse af tingene.
\end{abstract}

(Gadamer, 2004 s. 300)

Det er en eminent oneliner: Techne elsker Týche. Citatet rammer lige ind i mestringsforventninger og omsætning af viden til materialitet. Mestrer man en teknologi, vil man også lykkes med den og se potentialet for brug på andre felter. Mestrer man den ikke, vil man ikke blive tildelt denne Ahaoplevelse.

Al forståelse, også teknik, baserer sig ifølge Gadamer på horisontsammensmeltning, dvs. at noget nyt tilegnes i dele og integreres i en forståelseshelhed. Det særlige ved teknologiforståelse er, at det både har en vidensdimension, en handlingsdimension og en etisk dimension. Det betyder, at Aristoteles tre vidensformer alle er indlejret $\mathrm{i}$ teknologiforståelse, nemlig episteme (teoretisk viden), techne (anvendt viden) og fronesis (etisk dømmekraft). Hvis vi skal give eleverne teknologiforståelse, skal de dermed også have handlekompetence og etisk dømmekraft.

\title{
To typer teknologiforståelse
}

Al forklaring er som en forestående afdækning af det uforståelige
rodfæestet i tilstedeværens primære forståelse. Oprindeligt
eksistentielt begrebet vil forståelse sige: at være udkastende hen
imod en værenskunnen, for hvis skyld tilstedeværen netop eksisterer.

(Heidegger, 2007 s 371)

Det er Bibelen som helhed, der leder forståelsen af de enkelte dele, ligesom forståelsen af helheden kun kan opnås ved en samlet forståelse af delene. Dette cirkelforhold mellem helhed og del er ikke i sig selv noget nyt. Det er allerede kendt i den antikke retorik.

(Gadamer, 2004 s. 169)

De to citater rummer essensen af forståelse. Nederst ses Gadamers korteste udlægning af den hermeneutiske cirkel, øverst Heideggers bestemmelse af forståelse som noget andet og mere end forklaring. Forståelse knytter sig til et fremadrettet udkast mod at kunne noget. Forklaring er en efterrationalisering og logisk nedbrydning af en indsigt. 
Derved har vi indfanget noget væsentligt i to dominerende retninger inden for computer science: Computational Thinking og Design Thinking. Fælles for dem er nemlig, at de nedbryder et problem i dele og kaster sig frem mod løsningen af det, hvorefter de samler erkendelsen. Og et andet fællestræk er, at begge retninger har en forkærlighed for cirklen til at repræsentere den proces, som skaber teknologiforståelse.

Computational Thinking er baggrunden for projekter som Coding Class og First Lego League, og som bakkes op herhjemme af IT-branchen og Carlsbergfondets bestyrelsesformand Flemming Besenbacher, der i en kronik (Besenbacher \& Caspersen, 2017) slog til lyd for at gøre Computational Thinking til et obligatorisk fag i både gymnasiet og folkeskolen.

Der findes mange udgaver og definitioner af begrebet Computational Thinking, som har rødder i datalogi og informatik. I en hyppigt citeret viewpoint-artikel definerer professor i datalogi Jeanette M. Wing Computational Thinking sådan her:

\begin{abstract}
Computational methods and models give us the courage to solve problems and design systems that no one of us would be capable of tackling alone. Computational thinking confronts the riddle of machine intelligence: What can humans do better than computers? And what can computers do better than humans? (...) Computational thinking involves solving problems, designing systems, and understanding human behavior, by drawing on the concepts fundamental to computer science. Computational thinking includes a range of mental tools that reflect the breadth of the field of computer science. Having to solve a particular problem, we might ask: How difficult is it to solve? And what's the best way to solve it?
\end{abstract}

Konceptet bag Computational Thinking er at identificere et problem, nedbryde det $\mathrm{i}$ mindre dele, som baserer sig på kendte mønstre, som så sættes sammen til en helhed, hvilket udmønter sig i denne hermeneutiske cirkel: Se figur 13. Læg mærke til Yin og Yang-symbolet, der forbinder de komplementære områder mellem menneskelige evner og computerens affordances.

Anvender vi denne forståelse på vores case fra Ans, kan vi se, at eleverne i deres kollaborative samarbejde om programmeringen af Ozobotten følger cirklens progression ved at nedbryde ruten i små mønstre, som kan blokprogrammeres, samles og eksekveres. Kommandoerne er engelske, så der sker en medlæring, hvor julehistorien omsættes til et

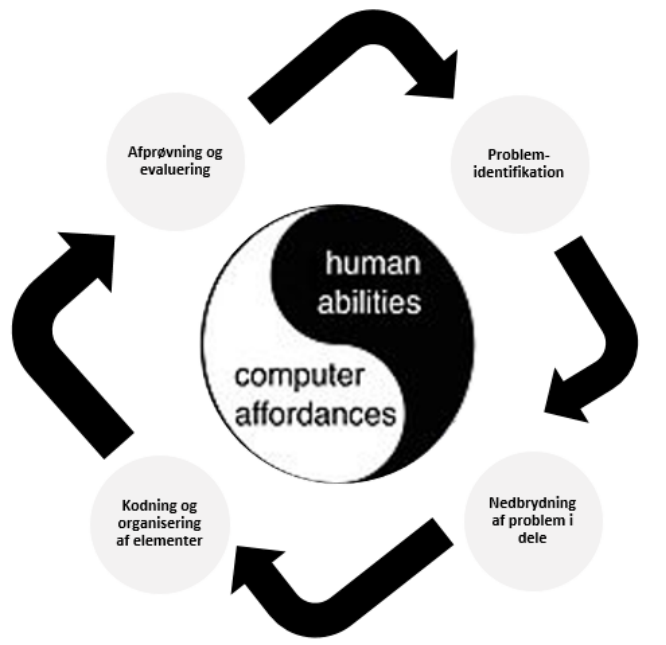

Figur 9: Hermeneutisk cirkel over Computational Thinking, frit tegnet efter https://en.wikipedia.org/wiki/Computational thinking 
scenarie, der appliceres på en repræsentation (bykortet), som lægger location til en rute, som eleverne nedbryder i mønstre og omsætter til kommandoer. Omsæt til ANT-perspektiv betyder det, at menneskelige og ikke-menneskelige aktører mødes i et fluktuerende netværk med skiftende aktører, for det er hver dag nye elever, der programmerer nye ruter ud fra nye narrativer.

Design Thinking stammer fra brugskunst og arkitektskoler, hvor man fra 1960'erne og frem har arbejdet bevidst med designskabelse. Fra 1980erne bliver tænkningen konceptualiseret og bragt ind i undervisningen, bl.a. på Stanford af Robert McKim, og gjort problemorienteret, sådan at designopgaver skal adressere virkelige problemer og behov. Det ses helt eksemplarisk udfoldet i Richard Buchanans dagsordensættende artikel "Wicked Problems in Design Thinking" (1992).

Begrebet Wicked Problems blev oprindeligt udformet af den tyske matematiker og designer Horst Rittel i 1960'erne og betegner et ondsindet problem, dvs. et autentisk problem, som der ikke er en given løsning på. Begrebets modsætning er 'tamme problemer', dvs. problemer, der er gennemlyste og løst på forskellig måde, fx bilers udstødning, belysning $\mathrm{i}$ foto eller afløb fra kloakker. Det interessante ved Design Thinking er, at man skal formulere behov eller problemer i relation til virkeligheden, som vi ikke har en tilfredsstillende løsning på endnu, fx plastikforurening af havene eller batterier med lang aktionsradius til biler.

Designtænkningen er siden blevet omsat til FabLab og Makerspaces i 2000-tallet og kraftigt udbredt i 2010'erne. Mindsettet bag er, at elever og borgere skal kunne fabrikere genstande med forskelige teknologier, fx 3Dprintere, vinylskærere og laser-cuttere samt analoge teknologier som metal- og træværktøjer, symaskiner og elektronik.

Didaktikken i maker-bevægelsen baserer sig på en kombination af konvergent og divergent læring, som det kendes fra Kolbs læringscirkel (Kolb, 1984). Der findes et hav af designcirkler, der mere eller mindre gennemgår de samme faser, der alle er varianter over den hermeneutiske cirkel. Vi vælger her at fokusere på Aarhus Universitets udgave af Stanfords designcirkel, der ser sådan ud: Se figur 10. 


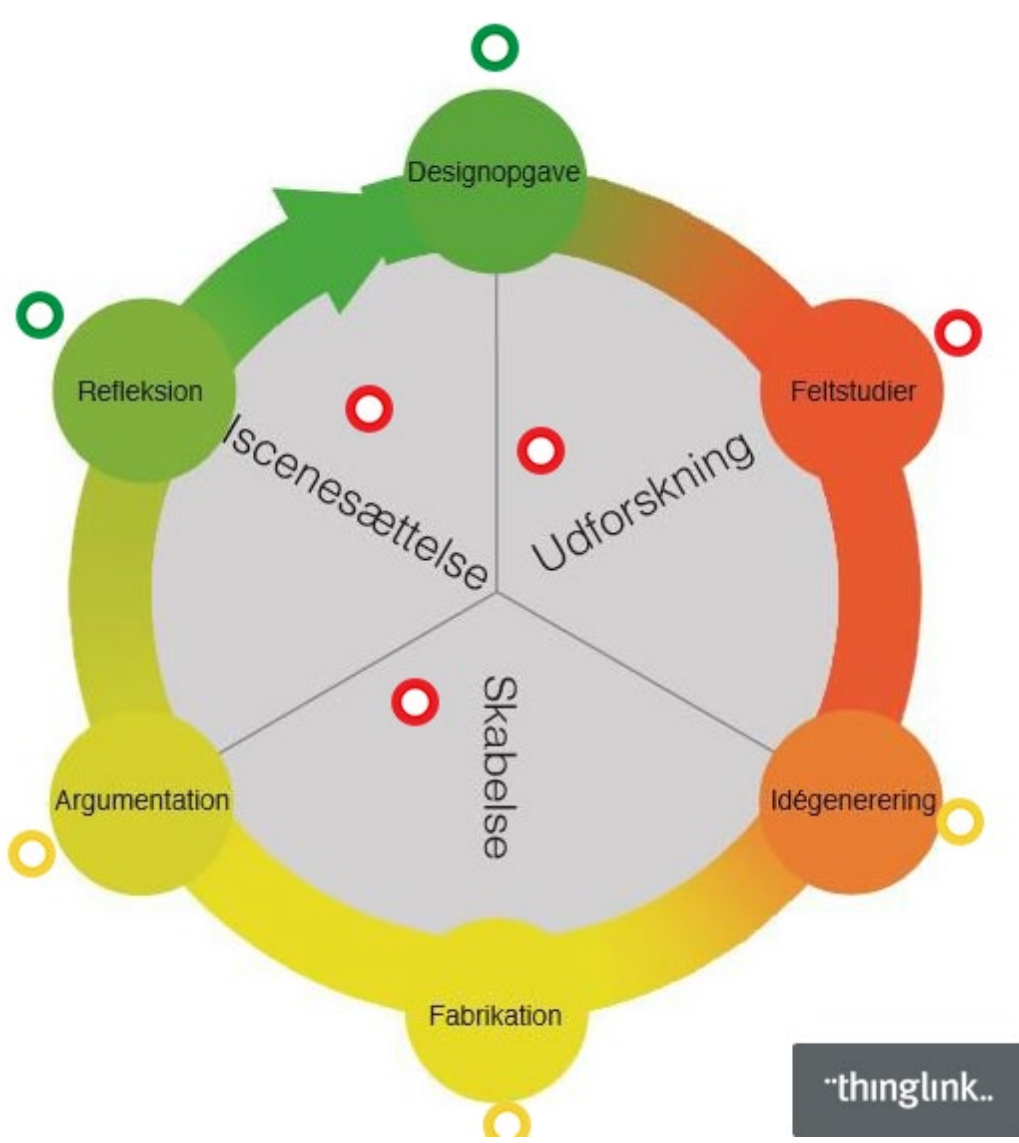

Figur 10: Designcirklen, som anvendes i FabLabs er oprindeligt udviklet på Stanford, men er fordansket af forskere fra Aarhus Universitet, men som blot er en variant af utallige modeller for Design Thinking (Se: http://fablabatschool.dk/designcirklen).Vi har sat cirklen ind i programmet ThingLink, således at der til hver af prikkerne er en forklaring, mens de tre prikker i midten åbner tre flipped classroom-videoer, vi har lavet til en workshop for 25 lærere og skoleledere. Find model og film her: https://www.thinglink.com/scene/1014468741657788417

Designopgaven kan enten blive stillet af et firma eller en underviser, men kan lige så ofte være brugerdefineret, sådan at elever eller designere selv skal formulere det problem, de vil finde løsningen på. Det er ikke alle problemer, der er lige ondsindede, men fælles for dem er, at de skal være verdensvendte og løse autentiske problemer. Af og til svigtes denne grundpille, fordi 3D-printere, laser-cuttere og vinylskærere frister til at ville løse opgaver, der passer til de affordances (Gibson 2015:119-35), som teknologien stiller til rådighed. Populært sagt forvandles alt til søm, hvis man har en hammer! Og alt til plastik, hvis man har en 3D-printer!

Cirklen har indlagt den selvdisciplinering, at man ikke må springe direkte fra problemidentifikationen til fabrikationen. Man skal researche først og diskutere alternative løsninger, før man idegenererer og laver en prototype. Denne skal begrundes og afprøves, hvilket ofte fører til iterative processer, hvor man produktudvikler og lærer ved at fejle. Også her er 
elever utålmodige. Ligesom de gerne vil springe feltstudierne over, er de ofte tilfredse med første forsøg og anstrenger sig ikke for at perfektionere en ide. Det er derfor en læreropgave at tvinge dem til at reflektere, afprøve, evaluere og re-designe. Det er en del af erkendelsens hermeneutiske cirkel, at øvelsen afsluttes med metarefleksion, hvor man fra helikopterperspektiv evaluerer processen og sprogliggør det lærte.

Det er heri, dannelsesdimensionen ligger. Eleverne løser problemer i den virkelige verden og lærer dermed noget om den, samtidig med at de anvender viden, mestrer en teknologi og ser dens begrænsninger. Vender vi blikket mod Ans, kan vi se, at 3D-produktionen af julepynt nok udgør et didaktisk og læringsmæssigt problem, men ikke en større udfordring i den virkelige verden. Udfordringen ligger i at pynte det juletræ, som en af forældrene har doneret, men det kunne lige så godt have foregået med analog klippe-klistre-aktivitet.

Læringsmæssigt ligger der en gevinst ved matematisk, geometrisk og abstrakt tænkning rettet mod at skabe en artefakt, som tilmed skal hænges på klassens juletræ. Eksemplet viser, at skolen ofte arbejder med kunstige problemstillinger for at forberede eleverne til det virkelige liv. Men det er kun delvist rigtigt. For det at designe brugsgenstande og pynte træer er en del af en juletradition, som blev indført i romantikken og kulturhistorisk har været med til at forme det fænomen, vi kalder jul.

Som sagt viste vores interviews, at eleverne ikke kan sprogliggøre deres læring, men nok udpege, hvad der var svært i den. Eleverne mangler blik for teknologiens anvendelsesmuligheder i et større perspektiv. Vi bliver derfor nødt til at diskutere, hvordan undervisning kan danne grundlag for dannelse for den enkelte, og det gør vi i næste afsnit.

\title{
Diskussion
}

\begin{abstract}
Mobilteknologi, robotteknologi og en stigende indlejring af mikroprocessorer i hverdagsting såsom biler, kaffemaskiner, tøj, bygningskomponenter og livsstilsprodukter skaber en hverdag, hvor teknologisk mestring er en forudsætning for at kunne leve det liv, vi ønsker. Vi skal forstå de præmisser, som teknologien sætter for vores virke og formåen - og samtidig forstå, hvordan vi kan designe vores digitale palet af muligheder, så den bedst muligt understøtter den måde, hvorpå den enkelte ønsker at leve sit liv. Igen synes den digitale teknologi at have ændret karakter fra et tilvalg til et grundvilkår.
\end{abstract}

(Iversen et al, 2019 s 14)

Citatet fra Ole sejer Iversen m.fl. er dækkende for et begreb om teknologiforståelse, hvor koblingen mellem teknologiernes intentionalitet og implikationerne for vores livsverden tydeliggøres. Teknologiens og i særdeleshed internettets udvikling har nemlig dramatisk ændret vores hverdagsliv og skolens praksisformer.

Internettets første fase brød lærerens vidensmonopol og gav adgang til alverdens hjemmesider og databaser. Anden fase gav os de sociale medier og 
en række web 2.0-teknologier, som gjorde det muligt at remediere, producere og dele viden. Tredje fase, det semantiske net, gav os cookies, digitale assistenter, intelligente søgninger, men også skjulte algoritmer, digital mobning, fake news og overvågning. Fjerde fase, tingenes internet, med robotter, kunstig intelligens og selvkørende biler, er under udvikling og vil skabe en verden af interaktive genstande, der kan tale sammen, og som fundamentalt vil ændre vores samfund inden for vores levetid.

Det rejser en række problemstillinger omkring, hvordan vi ruster eleverne til at navigere, deltage og forholde sig til de udfordringer, der, som citatet viser, bliver grundvilkår. Som vi skrev tidligere er begrebet om digital dannelse både inkonsistens som contradiction in terms, men også utidssvarende og inadækvat i forhold til det samfund, der omgiver os. Vores intervention i Ans har genereret det fund, at 3. klasses elever er gode til at samarbejde og sprogliggøre deres egne læreprocesser, men svage til at reflektere deres erfaring ud af klasseværelset. Det er der sådan set ikke noget overraskende i. Når man er 9-10 år, har man begrænset viden om verden og er endnu ikke i gang med de formative år for identitetsdannelse.

Pointen er, at Computational Thinking kan give dem værktøjer til at løse programmeringsopgaver, men ikke sætte dem i stand til selvstændigt at reflektere ud af boksen. Til gengæld kan en scenariedidaktik, som den vi udførte en miniature, sagtens udvides til at gælde den virkelige verdens problemer. I det sidste interview fortalte en af informanterne, at hendes far arbejdede med robotter til hverdag på et lokalt firma, UNIKA, der producerer plastik-elementer til forskellige virksomheder. Intet forhindrer, at man på den næste intervention bevæger sig over vejen til erhvervslivet for at hente en autentisk case med et wicked problem.

På samme måde ligger der i den iterative designproces muligheder for at gøre eleverne bevidste om valg og fravalg, som skal styrke elevernes evne til at se og tænke kritisk over den intentionalitet, der er indlejret i alle de produkter, der omgiver os:

Den empatiske og iterative udvikling af digitale artefakter har en betydelig sekundær, hvis ikke primær, gevinst i form at det dannelsesaspekt, som eleven tilegner sig gennem udviklingsprocessen. Ved kontinuerligt at eksponere eleven for de valg, fravalg, vurderinger og prioriteringer, som design indebærer, får eleven også mulighed for at forstå den intentionalitet, som alle digitale genstande rummer. "Hvis vi har måttet tage disse valg og fravalg gennem vores proces, hvordan har andre designere foretaget deres valg og fravalg, når de har designet teknologi for os?" Denne refleksive kompetence giver eleven en forståelse for og evne til at forandre de digitale teknologier, der er så determinerende for vores arbejds- og privatliv. Denne refleksivitet gør eleven i stand til at vælge til og ikke mindst vælge fra på et oplyst grundlag, når det kommer til egen anvendelse af digital teknologi.

(Iversen et al, 2018 s 17)

I december 2017 udgav professor Peter Bro sin bog om Aha-oplevelsen. Den handler om et bredt udsnit af Heureka-erfaringer, hvor en mulig løsning på et 
problem viser sig for en filosof, forsker eller et helt almindelig hverdagsmenneske. I Aha-oplevelsen indfinder der sig en pludselig sammenhæng mellem det at 'sinde' og det at 'finde'.

Begrebet 'sinde' henter Bro fra fysikeren H.C. Ørsted, der ved en tilfældighed opdagede sammenhængen mellem elektricitet og magnetisme. Det gjorde han kun, fordi hans sind var stemt i den retning. Det var det, fordi Ørsted som romantiker mente, at naturen er ånd, hvorfor alle ting måtte hænge organisk sammen i en helhed. Derfor var han sikker på, at der måtte være en sammenhæng, og fordi det optog ham, iagttog han den ved en tilfældighed forud for en forelæsning.

Begrebet 'finde' hænger sammen med at se sammenhænge og give et fænomen eksistens. Om det skriver Ørsted i sin dagbog, at "tilfælde, som er anledning til opdagelser, omgiver os i talløse mængder hver dag, men det er kun, når tilfældet møder den rette mand i det rette øjeblik, jeg mener et særligt lykke ligt øjeblik, at en opdagelse får tilværelse" (Bro, 2017 s. 23).

Det er disse Aha-oplevelser, design tænkning gerne skal give eleverne, hvorfor de skal lægges til rette. Det betyder, at skolen gennem fag - og gerne gennem et teknologifag - skal sinde eleverne, dvs. give dem viden og baggrund for, at de selv kan tænke og udforske problemer. Det kræver, at man kan tænke både konvergent og divergent, så man 'vender' en kendt tænkning om og får øje på noget fra en ny eller anden vinkel.

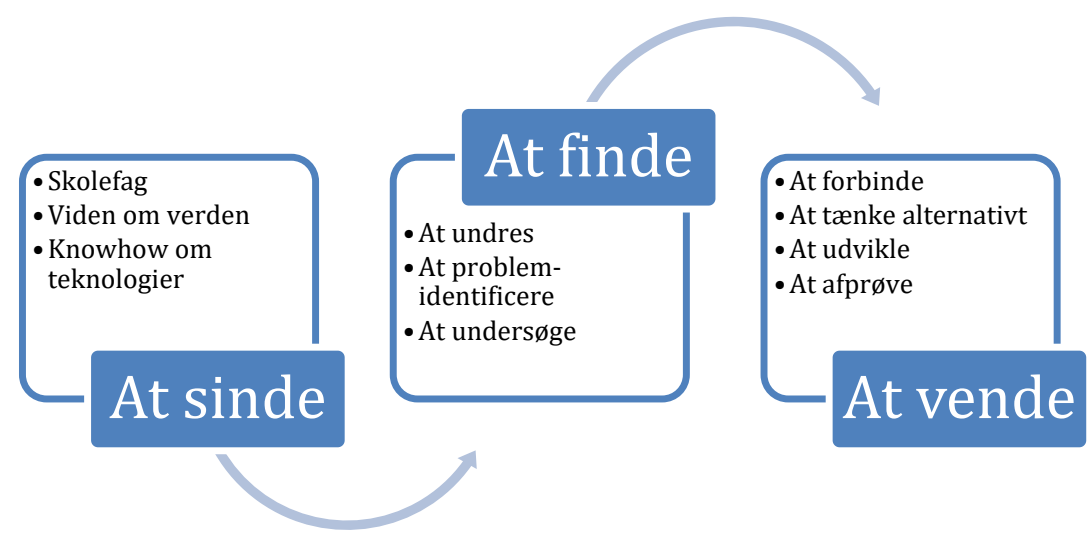

Figur 11: Progressionen i en Aha-oplevelse, frit efter Bro, 2017 s. 37.

For at fremkalde egentlige Aha-oplevelser gælder det om at tilrettelægge en undervisning, der fremmer divergent tænkning, hvilket kun kan ske på et kvalificeret niveau, hvis eleverne har styr på materien, dvs. det problemfelt, som man skal arbejde i. Derfor skal undervisningen stilladsere det nødvendige vidensgrundlag, så man kan sinde eleverne og dermed kvalificere deres fund. Man kan ikke være kreativ uden rammer, uden viden og uden knowhow. Det er derfor, at feltstudierne i designcirklen er vigtige. Teoretisk er Bros Ahamodel i tråd med Heideggers begreb om udkast og Gadamers hermeneutiske cirkel, hvor vi vender det ukendte og integrerer det i vores horisont.

Denne artikels teorivalg er begrundet i begrebet teknologiforståelse. For at forstå teknologi som fænomen er trioen Aristoteles, Heidegger og Latour valgt, fordi førstnævnte udpeger de tre samspillende vidensformer episteme, 
techne og fronesis og som bærende i omgangen med teknologi: viden, håndtering og etisk dømmekraft. Heidegger er central, fordi han forbinder forståelsesdimensionen med den skjulte side af teknikken, mens Latour peger på samspillet mellem menneskelige aktører og ting i netværk. David Miller supplerer trioen med et materialitetsbegreb, som betyder noget for læring og menneskets forståelse af verden. Og i relation til forståelsesbegrebet er Gadamers hermeneutik uomgængelig for at forklare, hvad en forståelse egentlig er.

Denne artikels empiriske materiale er valgt for at understøtte udforskningen af elevers teknologiforståelse. Gennem observationer, video og interview er vi blevet klogere på, hvor transferproblematikken ligger. Den ligger i evnen til at forstå teknologierne i relation til vores hverdagsliv og samfund. Det er ikke overraskende, at elever i 3. klasse ikke kan løfte den udfordring, men det skal de heller ikke. De første erfaringer skal følges op af flere, sådan at eleverne gradvist bliver klogere på sig selv og verden.

Det samme gælder vores undersøgelse. Den kan slet ikke stå alene, men rummer en første udforskning af et felt, som lige nu er under udvikling. Vores mål har ikke været at skabe evidens, for vores intervention er ikke forskning, men en refleksion over praksis. Derfor er forløbet blevet vores analyseenhed og det, der binder hele artiklen sammen.

\section{Konklusion}

Vores fund kan opsummeres sådan her: Eleverne lykkes med at designe og 3D-printe deres egen julepynt og med at programmere Ozobotten til at gennemløbe den rute, som julefortællingen foreskrev. De laver fin transfer fra fiktionen til repræsentationen af Ans by. Deres læse- og scenarieforståelse var dækkende, og de var gode til at sætte ord på deres egne læreprocesser. Det afgørende fund var imidlertid, at eleverne mangler evne til at kunne omsætte det lærte i en egentlig teknologiforståelse. Det hænger dels sammen med deres alder, sprogudvikling og viden om verden, dels med forløbets design. Som sagt i sidste afsnit kan en intervention ikke løfte opgaven. Udviklingen af elevernes teknologiforståelse er et langvarigt projekt, der vil fortsætte i gymnasiet og ud i fremtiden, da samfundets teknologiske udvikling er accelereret.

I forlængelse af artiklens argumentation kan vi konkludere, at et tidssvarende dannelsesbegreb handler om at give eleverne viden og værktøjer, så de kan se sig selv i og gennem det samfund, som de skal deltage i. Derfor involverer et tidssvarende dannelsesbegreb ikke teknologiforståelse som et instrumentelt script, som det kendes fra informatik og edb-fag, men som en udforskning af, hvordan teknologi fungerer i verden, herunder i medier og et medialiseret samfund.

Dannelse handler derfor om at forstå de forandringer, som digital teknologi har gennemsat i samfundet, og hvordan vi alle på godt og ondt er filtret ind i teknologi (Se Fibiger, 2017). Målet er at sinde eleverne, så de selv kan vende problemer og finde løsninger. Derfor er handlekompetence og empowerment udgøre en central del af dannelsen, sådan at teknologien 
hjælper individet til at handle i hverdagen, både med at forstå og bemestre sin livsverden.

\section{Referencer}

Besenbacher, F \& Caspersen, M.E. (2017): " Faren er dumme mennesker. Ikke kloge robotter". Politiken 4.12.2017.

Biesta, Gert (2014): "Når 'hvad der virker' stadigvæk ikke virker". In Uren pædagogik 2. Klim.

Bro, Peter (2017): Aha-oplevelsen. Arven fra Alfred Nobel. Syddansk Universitetsforlag.

Brudholm, Mette (2011): Læseforståelse - hvorfor og hvordan. Akademisk forlag.

Buchanan, Richard (1992): "Wicked Problems in Design Thinking" in Design Issues, Vol. 8, No. 2, 1992, pp. 5-21 Published by: The MIT Press Stable URL: http://www.jstor.org/stable/1511637

Bundsgaard, Misfeldt \& Hetmar (2012): "Literacy i scenariebaserede undervisningsforløb" in Viden om læsning nr. 4. 2012.

Faurby, B. (2001): Jagten på den forsvundne julestjerne - en julehistorie i 24 afsnit. Forum.

Fibiger, J. (2017): Filtret ind - et aktør-netværkperspektiv på medieret undervisning. København. Samfundslitteratur.

Flyvbjerg, Bent (2010): "Fem misforståelser om casestudiet" in Brinkmann, S \& Tanggaard (red): Kvalitative metoder. Hans Reitzels forlag.

Gadamer, Hans Georg (2004): Sandhed og metode. Systime.

Gibson, James (2015): The Ecological approach to Vision Perception. Psychology Press.

Giddens, Anthony (1982): Profiles and Critiques in Social Theory. University of

California Press.

Giddens, Anthony (1984): The Constitution of Society: Outline of the Theory of

Structuration. Polity Press.

Hammershøj, Lars Geer (2017): Dannelse i uddannelsessystemet. Hans Reitzels forlag.

Hansen, B.B. \& Ingemann, J.H. (2016): At se verden i et sandkorn.

Samfundslitteratur.

Hegel, G.W.F. (2005): Åndens fæenomenologi. Gyldendal.

Heidegger, Martin (1999): Spørgsmålet om teknikken. Gyldendal.

Heidegger, Martin (2007): Væren og tid. Klim.

Humboldt, Wilhelm von (1986): Theorie der Bildung des Menschen. Juventa-Verlag.

Iversen, O. S. et al. (2019): Digital teknologi og design. Frederikshavn. Dafolo.

Klafki, Wolfgang (1996): "Kategorial dannelse" in Erling Lars Dale: Skolens undervisning og barnets utvikling. Ad Notam. Norsk Gyldendal.

Kolb, David A. (1984): Experiental learning. Prentice-Hall.

Latour, Bruno (1996): "Om aktør-netværk-teori" in Philosophia nr. 25. 1996.

Latour, Bruno (1999): Pandoras Hope. Harward UP.

Latour, Bruno (2006): Vi har aldrig været moderne. Hans Reitzels forlag

Latour, Bruno (2004): "Why have Critique Run out of Steam". Critical inquiry 30. University of Chicago.

Miller, Daniel (2005): Materiality. Duke. University Press.

Neergaard, Helle (2007): Udvælgelse af cases. Samfundslitteratur.

Oettingen, Alexander von (2016): Almen didaktik. Hans Reitzels forlag.

Papert, S. (1993): Mindstorms. USA. Basic Books.

Ramian, Knud (2007): Casestudiet i praksis. Academica.

Schön, Donald (2001): Den reflekterende praktiker. Klim. 
Skov, A. \& Brøndum, J. (2016): "Hvad betyder digital dannelse?" Center for Digital Dannelse. https://digitaldannelse.org/vidensbase/hvad-betyder-digital-dannelse/ (downloadet 1.1. 2018).

Wing, J.M (2006): “Computational Thinking” in COMMUNICATIONS OF THE ACM. March 2006/Vol. 49, No. 3

Wing, J.M (2008): "Computational Thinking and thinking about computing"

http://rsta.royalsocietypublishing.org/content/366/1881/3717 (Hentet 1.1. 2018). Yin, Robert (2009): Case Study Research. $4^{\text {th }}$ edition. Sage Publications Inc. 